\title{
Impacts of Climate and Land-Use Change on Runoff (Case Study: Balighloo Chai Basin, Iran)
}

\author{
B. Farokhzadeh, S. Choobeh, and H. Nouri
}

\begin{abstract}
Global climate changes due to increased greenhouse gases and changes in land use such as urbanization pose challenges for conservation strategies. In this research to assessment the effects of climate changes in Balighloo Chai basin, during the 2050s, A2 and B1 scenarios were downscaled with LARS-WG and were compared with the 1983-2013 period. Results showed the increase between $\mathbf{- 0 . 4 7}$ to 3.09 percent in average annual rainfall and the increase between 1.80 to $2.02{ }^{\circ} \mathrm{C}$ in average temperature in the 2050s. Two land use scenarios were developed to predict the impact of land use changes on the runoff in the coming decades: in the first scenario the current land use assumed fixed and unchangeable in future and in the second scenario assumed the same trend of changes which has occurred in the past (continuation of the past changes) . Results show a decrease of 41 percent in rangelands area and 21 percent increase in agricultural area to 2050s. In order to simulate the hydrologic system in the coming decades, HEC-HMS model calibrated and validated using real data. Results showed increase of peak flow and flood volume in April and decrease of peak flow and flood volume in March, May, and June. If land use change occurs with climate change, this changes will be intensified.
\end{abstract}

Index Terms-Climate change, downscaling, HEC-HMS, land use change, LARS-WG.

\section{INTRODUCTION}

Soil, topography and land cover are the most important factors that impress rainfall-runoff processes at river basins. As alterations in soil and topography, are insignificant in the short term, Land cover changes are supposed to be an important factor in modifying rainfall-runoff processes [1]. Global Climate change is a major concern in the present century [2]. Rapid urbanization leads to sharp changes in land use pattern and strongly impress the hydrological processes in a catchment. The increase in impervious areas interrupts the natural water balance and decreased infiltration increases runoff and results in higher flood peaks.

Extreme precipitation events which causes flood, have been an increasing concern for many regions throughout the world [3]. There is a strong correlation between climate changes affiliated to rising temperatures and flooding induced by storm events [4]-[6]. In past years, the number of publications and research on climate change and how it might impress different hydrograph sections (precipitation, runoff,

Manuscript received November 12, 2017; revised January 13, 2018.

B. Farokhzadeh and H. Nouri are with the Range and Watershed Management Department, Faculty of Natural Resources and Environmental Sciences, Malayer University, Malayer, Iran (corresponding author: B. Farokhzadeh; e-mail: b.farokhzadeh@malayeru.ac.ir, hamidwatershed@yahoo.com)

S. Choobeh is with Watershed Management, Urmia University, Iran (e-mail: sepideh.choobeh@yahoo.com). etc.) has constantly grown up among them, a number of published papers focus on the hydrologic cycle and water resources such as [7]-[13]. Wan and Yang (2007) in their study illustrated that anthropogenic land-use change is one of the major drivers of an increased frequency of flooding incidents [14].

Where a number of studies have shown no significant change in flooding pattern with deforestation [15], [16] others have even reported a negative trend in flood occurrence with reductions in forest cover [17].

Van Dijk et al. (2009) illustrated that the empirical evidence and theoretical arguments for increased flood intensity with the removal of forest are not very convincing [18]. Hydrological modeling is a common tool to explanation the basin's hydrological response due to precipitation. The selection of the model depends on the basin and the objective of the hydrological prediction in the basin. Chen et al.(2009) used an LULC scenario-generation model with a hydrological model and concluded that increasing urban areas led to increases in the total runoff volume and peak discharge of storm runoff events[19]. In the present study, we made an attempt to estimate the effect of climate and land use changes on the hydrograph in Balighloo chai watershed in Ardebil province of Iran via using local weather trends and IPCC climate scenarios and precipitation- runoff model (HEC-HMS).

\section{MATERIALS AND METHODS}

\section{A. Study Region}

This present study was carried out at the Balighloo Chai basin, a tributary of the river Gharesoo located in Ardebil Province in Northwestern Iran (Fig. 1), which lie between latitude $37^{\circ} 46^{\prime} 38^{\prime \prime}$ to $38^{\circ} 22^{\prime} 52^{\prime \prime} \mathrm{N}$ and longitude $47^{\circ} 46^{\prime} 28^{\prime \prime}$ to $48^{\circ} 42^{\prime} 11^{\prime \prime}$ E. Balighloo Chai basin covers an area of approximately $1036 \mathrm{~km} 2$ and regulated by several small dams and one large dam (Yamchi) in its upper part. Since the 1990s, the basin has undergone drastic changes, the most important of these is an increase of 13 percent in the agricultural lands this leads to growing concern for future water resource availability, which will be potentially affected by climate change.

\section{B. Calibration of LARS-WG}

Reliable and continuous meteorological data from climate models are basic inputs. Therefore, in this study, Ardabil synoptic station with long-term statistics is used. At first, a base scenario which does not apply climate changes in the period 1983-2013 developed and its ability to reproduce the observed data were analyzed. The output of minimum and maximum temperature and precipitation, as well as the 
standard deviation of the study area, were compared to 30 years observed data. Evaluation of LARS-WG has been done by comparing baseline and synthetic data that generated by the model, using comparative charts and statistical parameters including RMSE, and NSE. These statistics have been calculated using equations 1 to 2 .

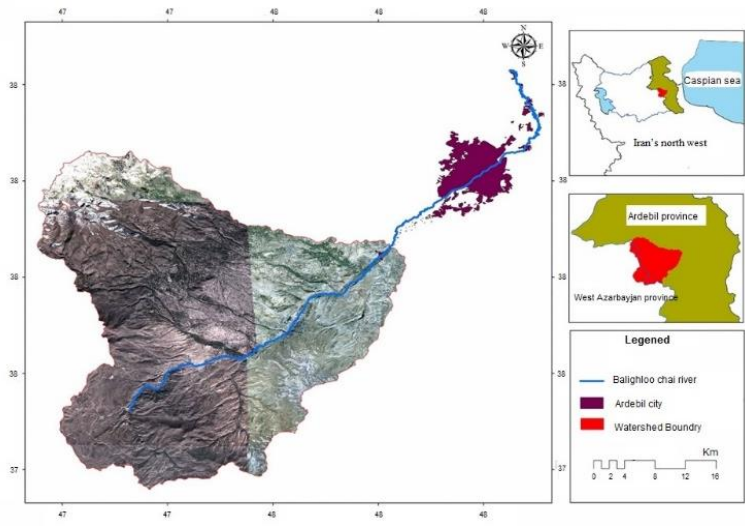

Fig. 1. The position of Balighloo Chai basin in Ardebil provinc.

$$
\begin{array}{r}
\mathrm{NSE}=\left[1-\frac{\sum\left(\mathrm{x}_{\mathrm{o}}-\mathrm{X}_{\mathrm{S}}\right)^{2}}{\sum\left(\mathrm{X}_{\mathrm{o}}-\overline{\mathrm{X}}_{\mathrm{o}}\right)^{2}}\right] \\
\mathrm{RMSE}=\sqrt{\frac{\sum\left(\mathrm{X}_{\mathrm{O}}-\mathrm{X}_{\mathrm{S}}\right)^{2}}{\mathrm{~N}}}
\end{array}
$$

where X0: Observed data, XS: Simulated data, Average of observed data and N: Number of data. Also, The K-S statistical test to compare the frequency distributions, T.test to compare mean values and F.test to compare the standard deviation of the observed data and modeling was used. After ensuring the ability of LARS-WG in the production of climate data, this model was conducted for downscaling The HADCM3 model and synthetic data to predict the climate for the years 2011 to 2030. Two emission scenarios A2 and B1 [20] were used and minimum and maximum temperature, and daily precipitation were used for the downscaling.

\section{Land Use Scenarios}

For evaluating the impact of climate change on the hydrology of the study region, two following steps were considered, first generating preliminary land use map, and then prediction land use map in future. The current land use in the Balighloo Chai watershed includes $45 \%$ Rangeland, 35\% farming areas, $15 \%$ residential areas and $5 \%$ bare lands. Two scenarios were developed to predict the impact of land use changes on the runoff in the coming decades: : in the first scenario (SN1) the current land use assumed fixed and unchangeable in future and in the second scenario (SN2) assumed the same trend of changes which has occurred in the past (continuation of the past changes).

\section{Flood Hydrograph Simulation in the Future under Climate and Land Use Change Scenarios}

The effects of climate and land use change on runoff in the Balighloo Chai watershed is examined using the capabilities of the hydrological model HEC-HMS. HEC-HMS (Hydrologic Engineering Center - Hydrologic Modeling System) model was established in US Army Corps of Engineers [21] that could be implemented for many hydrological process. In this study to simulate future changes in runoff hydrograph, changing in rainfall hyetograph (for considering climate change) and changing in $\mathrm{CN}$ number (for considering land use change) is executed. It should be noted, despite the change in the amount of precipitation for the future, rainfall pattern is assumed without changing. After running the model with land use and climate change scenarios, simulated and observed hydrograph for the future period were compared. For validating model efficiency, 4 independent flood events were used for calibration. in validation process Performance of model to simulate flood hydrograph was validated, using Nash-Sutcliffe [22] and bias.

\section{RESUlts}

\section{A. Future Climate Change}

The simulated and observed climate data for the baseline period (1983-2013) were compared using the statistical tests in the LARS-WG. The results show no significant difference between the observed and simulated data because p-values for all tests were more than 0.05 , suggesting that the results derived from the LARSWG were reasonable to project climate change [23]. Daily precipitation, maximum and minimum temperatures for the future periods were projected by the LARS-WG with the SRES A2 and B1 scenario. Average monthly maximum and minimum temperatures in the future periods were predicted to increase in all months relative to the baseline period. For the time period, 20462065 , the greatest increase in maximum temperature $\left(3.11^{\circ} \mathrm{C}\right)$ was in July and the smallest increase $\left(0.65^{\circ} \mathrm{C}\right)$ was in January (Fig 2. a). The average annual maximum temperature increased from $9.07{ }^{\circ} \mathrm{C}$ in the baseline period (1983-2013) to $11.02{ }^{\circ} \mathrm{C}$ under $\mathrm{A} 2$ scenario and 10.80 under the $\mathrm{B} 2$ scenario in the mid-21st century (2046-2065). For average monthly minimum temperature, the greatest change $\left(3.06{ }^{\circ} \mathrm{C}\right.$ under $\mathrm{A} 2$ scenario was in July in (2046-2065), while the smallest change $\left(0.85{ }^{\circ} \mathrm{C}\right.$ under B1 scenario was in January in (20462065) (Fig. 2 b). The annual precipitation decreased by $0.47 \%$ under B1 scenario and increased $3.09 \%$ under the A2 scenario in the future periods (Fig. 2 C).
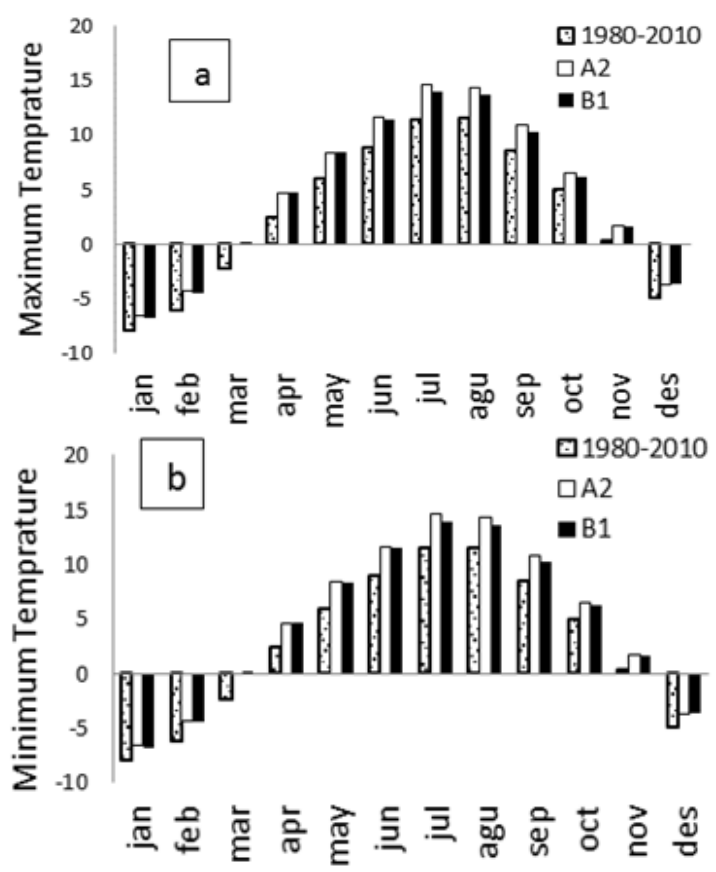


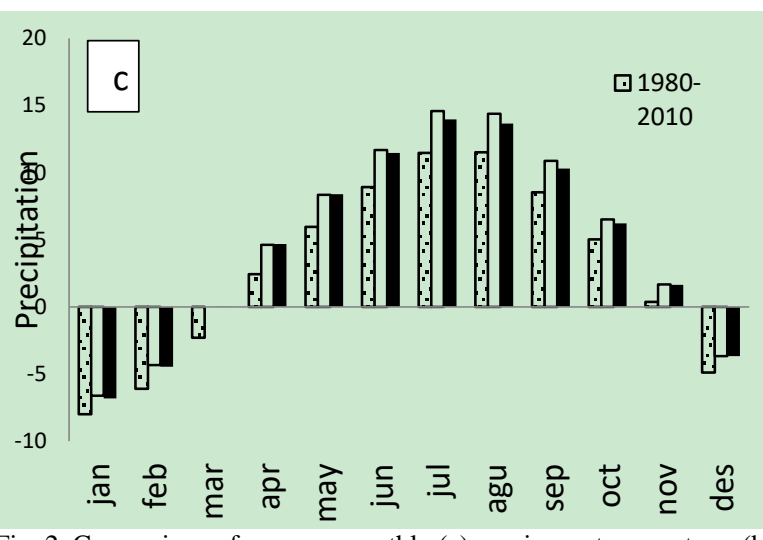

Fig. 2. Comparison of average monthly (a) maximum temperature, (b) minimum temperature, and (c) precipitation for the 1983-2013 (baseline), 2046-2065 period.

\section{B. Predicted Land Use Change Analysis between 2013 and the Future}

Generating the Balighloo Chai land use maps for two scenarios ( $\mathrm{SN} 1$ and $\mathrm{SN} 2$ ) showed that the sizes of residential areas, agriculture, and bare land increased compared to 2013 (Table I) and rangelands are estimated to decrease in future.

TABLE I: PERCENT OF LAND USE ClASSES IN THE BASE PERIOD (2013) AND THE FUTURE (2050)

\begin{tabular}{lllll}
\hline \hline Year & Rangeland & Agriculture & Residential & bare land \\
\hline 2013 & 45 & 35 & 15 & 5 \\
2050 & 4 & 56 & 30 & 9 \\
\hline
\end{tabular}

\section{Effect of Climate and Land Use Changes Scenarios on Hydrologic Response}

In this study 7 storm records were used to evaluate surface runoff and Peak flow. 3 storm events were selected randomly for model calibration and other 4 events for model validation. The coefficient of determination NSE and PBIAS were 0.80 , 0.70 and $29.73 \%$, respectively, for the calibration period and $0.85,0.76$ and $21.52 \%$, respectively, for the validation events.

Model performance in simulating Peak discharge Volume of discharge response was considered good based on NSE and PBIAS values for the calibration and validation periods, which were $0.78,0.71,30.22 \%$ and $0.83,0.78,18.23 \%$ respectively. Calibration results showed that optimal initial losses are 0.133 of total loss. So using a modified CN initial losses for subwatershed were calculated. The calibrated HEC-HMS model was applied to each of the climate and land use change scenarios to assess the effects of these changes on flood events. 4 flood events with different magnitude peak discharges were selected to assess the potential change in response to climate change and urbanization. The simulation results are presented in Table II, where it can be seen that: 1) land use change affect peak flows and runoff volumes more than long-term runoff, and 2) the flood volumes increase slightly more than flood peaks for the same increase of impervious surface ratio. These results are similar to [24]-[26]. The increase in flood volume rather than flow peak would result in an increase of the duration of flood inundation. As mentioned, the future temperature and precipitation for 2050 by $\mathrm{Had}$ CM3 showed a maximum temperature increase of $1.8^{\circ} \mathrm{C}$ and $2.2^{\circ} \mathrm{C}$, respectively, and a drop in annual precipitation of $-0.47 \%$ and $3.9 \%$ for $\mathrm{A} 2$ and
B1 SRES, respectively, compared to the 1983-2013. This fact will contribute significantly not only to surface runoff and recharge rate decreases (due to a lower amount of available water), but also to higher evapotranspiration ( due to a temperature increase), which may cause reduced soil water content, and higher or earlier water deficits, in the root zone. The results showed, no change in the intensity and frequency of extreme events and rainfall variability. As can be seen in Table II, A2, L1 and B1, L1 scenarios have predicted for the March, May, and June reducing the flood because of reduced rainfall, while for April increasing in peak and amount of flow due to changing the type of rainfall and transition of rainfall pattern from snow to rain.

TABLE II: COMPARISON OF PEAK FLOW AND VOLUME FLOW FOR THE 1983-2013 (BASELINE), 2046-2065 PERIOD

\begin{tabular}{|c|c|c|c|c|c|c|}
\hline Month & Parameter & Base & $\begin{array}{l}\text { A2, } \\
\text { L1 }\end{array}$ & B1L1 & A2L2 & B2L2 \\
\hline \multirow[t]{2}{*}{ March } & Peak flow(m3/s) & 18.4 & 15.2 & 9.4 & 18.7 & 11.8 \\
\hline & $\begin{array}{l}\text { Flood } \\
\text { volume }(1000 \mathrm{~m} 3)\end{array}$ & 565.7 & 433.2 & 287.4 & 523 & 545.3 \\
\hline \multirow[t]{2}{*}{ April } & Peak flow $(\mathrm{m} 3 / \mathrm{s})$ & 0.8 & 1.7 & 0.7 & 2.3 & 0.8 \\
\hline & $\begin{array}{l}\text { Flood } \\
\text { volume }(1000 \mathrm{~m} 3)\end{array}$ & 29.2 & 60.6 & 24.6 & 75.6 & 29.2 \\
\hline \multirow[t]{2}{*}{ May } & Peak flow(m3/s) & 33.4 & 17 & 9.4 & 20.6 & 11.7 \\
\hline & $\begin{array}{l}\text { Flood } \\
\text { volume }(1000 \mathrm{~m} 3)\end{array}$ & 862.6 & 474.1 & 280.2 & 569.4 & 338.1 \\
\hline \multirow[t]{2}{*}{ June } & Peak flow(m3/s) & 0.7 & 9.1 & 8.5 & 11.2 & 10.4 \\
\hline & $\begin{array}{l}\text { Flood } \\
\text { volume }(1000 \mathrm{~m} 3)\end{array}$ & 26 & 280 & 266 & 337.2 & 317 \\
\hline
\end{tabular}

Despite B1 scenario which shows a decrease of rain in 2050 decade, scenario B1L2 illustrates the increase in peak and amount of flow more than B1L1. This event shows the effect of land use change on runoff. As can be seen A2 and B1 in March, May and June predicts a decline in flood due to decline in rainfall while for April increased peak and amount of flow. According to the scenarios A2, L1 and B1, L1 with no land use changes, Average monthly peak flow and the amount of flood in the future periods were predicted to increase in April and June and decrease in March and May in the future periods under A2L1. The results show that changes of floods in April compared to other months will be sharply (due to increase in rainfall).

\section{CONCLUSION}

In this research to assessment the effects of climate change in Balighloo Chai basin, during the 2050s, A2 and B1 scenarios were downscaled with LARS-WG and were compared with the 1983-2013 period. Results showed that the increase of rainfall is accompanied by temperature increase so the increase of rainfall will not improve the amount of water accessibility. As mentioned above, rainfall will decrease in the spring and summer while the maximum temperature will occur in this seasons so water supplies would decrease. Since this watershed is one of the most important regions for supplying water, the water crisis will be 
inevitable in future periods. Land use changes cause increase of flood and runoff and worsen the climate changes impacts. In the coming decades, if the land use changes continue with climate change, flood volume will be increased a lot.

\section{REFERENCES}

[1] S. N. Miller et al., "Integrating landscape assessment and hydrologic modeling for land cover change analysis, JAWRA," Journal of the American Water Resources Association, vol. 38, pp. 915-929, 2002.

[2] S. Chattaraj et al., "Hyperspectral remote sensing for growth-stage-specific water use in wheat," Field Crops Res., vol. 114, pp. 179-191, 2013.

[3] T. Huntington, "Evidence for intensification of the global water cycle: review and synthesis," Journal of Hydrology, pp. 83-95, 2006.

[4] G. Lenderink and E. Meijgaard, "Increase in hourly precipitation extremes beyond expectations from temperature changes," Nature Geoscience, vol. 1, p. 511e514, 2008.

[5] S. K. Min et al., "Human contribution to more-intense precipitation extremes," Nature, vol. 470, p. 376e379, 2011.

[6] R. A. Pielke and M. W. Downton, "Precipitation and damaging floods: Trends in the United States," Journal of Climate, vol. 20, p. 3625e3637, 2000.

[7] E. K. Hartig et al., "Climate change, agriculture and wetlands in Eastern Europe: Vulnerability, adaptation, and policy," Clim Change, 1997, vol. 36, pp. 107-21.

[8] A. Werritty, "Living with uncertainty: climate change, river flows, and water resource management in Scotland," Sci Total Environ., 2002, vol. 294, pp. $29-40$.

[9] R. L. Wilby et al., "Integrated modeling of climate change impacts on water resources and quality in a lowland catchment: River Kennet, UK," J Hydrol., 2006, vol. 330, pp. 204-20.

[10] D. A. Burns et al., "Recent climate trends and implications for water resources in the Catskill Mountain region, New York, USA," J Hydrol., 2007, vol. 336, pp. 155-70.

[11] W. Hagg et al., "Modeling of hydrological response to climate change in glacierized Central Asia catchments," J Hydrol., 2007, vol. 332, pp. 40-53.

[12] M. Ruth et al., "Adaptation of urban water supply infrastructure to impacts from climate and socioeconomic changes: The case of Hamilton, New Zealand," Water Resour Manage, 2007, vol. 21, pp. $1013-45$.

[13] M. L. Grieneisen and M. Zhang, "The current status of climate change research," Nat Clim Change, 2011, vol. 1, pp. 72-3.

[14] R. Wan and G. Yang, "Influence of land use/cover change on storm runoff - A case study of Xitiaoxi River Basin in upstream of Taihu Lake watershed," Chin. Geogr. Sci., vol. 17, no. 4, pp. 349-356, 2007.

[15] V. Andréassian, "Water and forests: from historical controversy to scientific debate," J. Hydrol., vol. 29, pp. 1-27, 2004.
[16] R. L. Beschta et al., "Peak flow responses to forest practices in the western Cascades of Oregon, USA,” J. Hydrol., vol. 233, pp. 102-120, 2000.

[17] J. W. Hornbeck et al., "Summary of water yield experiments at Hubbard Brook Experimental Forest, New Hampshire," Can. J. For. Res., vol. 27, pp. 2043-2052, 1997.

[18] N. A. Chappell et al., "Forest-flood relation still tenuous-comment on 'Global evidence that deforestation amplifies flood risk and severity in the developing world'," Global Change Biol., vol. 15, pp. 110-115, 2009.

[19] Y. Chen et al., "Impacts of land use change scenarios on storm-runoff generation in Xitiaoxi basin, China," Quat. Int., vol. 208, pp. 121-128, 2009.

[20] IPCC, "General guidelines on the use of scenario data for climate impact and adaptation assessment," 2007.

[21] A. D. Feldman, "Hydrologic modeling system HEC-HMS, technical reference manual," U.S. Army Corps of Engineers, Hydrologic Engineering Center, HEC, Davis, CA, USA, 2000.

[22] J. E. Nash and J. E. Sutcliffe, "River flow forecasting through conceptual models. Part 1: A discussion of principles," J. Hydrol., vol. 10, pp. 282-290, 1970 .

[23] M. A. Semenov and E. M. Barrow, "LARS-WG: A stochastic weather generator for use in climate impact studies," Rothamsted Res., 2002.

[24] D. W. Dreher and H. T. Price, "Reducing the impacts of urban runoff The advantages of alternative site design approaches," Northeastern Illinois Planning Commission, Chicago. 1997.

[25] S. Im et al., "Simulating hydrologic and water quality impacts in an urbanizing watershed," J. Am. Water Resour. Assoc., vol. 39, pp. 1465 $1479,2003$.

[26] M. I. Hejazi and M. Markus, "Impacts of urbanization and climate variability on floods in Northeastern Illinois," J. Hydrol. Eng., vol. 14, no. 6, pp. 606-616, 2009.

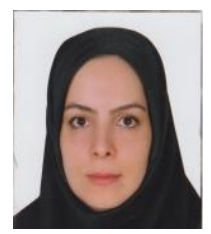

Behnoush Farokhzadeh is the head of the Range \& Watershed Management Department, Faculty of Natural Resources and Environmental Sciences. Malayer University - Malayer-Iran. She is $\mathrm{PhD}$ of watershed management, University of Tehran, Iran.

Sepideh Chobe is $\mathrm{PhD}$ student of Watershed Management, Urmia University, Urmia, Iran. She is MSc of watershed management, Malayer University, Iran

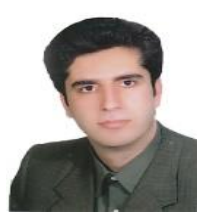

Hamid Nouri is with the Range \& Watershed Management Department, Faculty of Natural Resources and Environmental Sciences. Malayer University Malayer-Iran. $\mathrm{He}$ is $\mathrm{PhD}$ of Climatology, Isfahan University, Iran. 